\title{
Reply to the comment on "Mudflat/distal fan and shallow lake sedimentation (upper Vallesian-Turolian) in the Tianshui Basin, Central China: Evidence against the late Miocene eolian loess" by A.M. Alonso-Zarza, Z. Zhao, C.H. Song, J.J. Li, J. Zhang, A. Martín-Pérez, R. Martín-García, X.X. Wang, Y. Zhang and M.H. Zhang
}

\author{
A.M. Alonso-Zarza a,*, Z. Zhao ${ }^{\text {b }}$, C.H. Song ${ }^{\text {c }}$, J.J. Li ${ }^{\text {c }}$, J. Zhang ${ }^{\text {c }}$, A. Martín-Pérez ${ }^{\text {a }}$, R. Martín-García ${ }^{a}$, \\ X.X. Wang ${ }^{c}$, Y. Zhang ${ }^{c}$, M.H. Zhang ${ }^{b}$, A. Meléndez ${ }^{d}$ \\ a Dept Petrología y Geoquímica, Facultad de Ciencias Geológicas, Universidad Complutense, IGE-CSIC, 28040 Madrid, Spain \\ b Jiangsu Key Laboratory of Environmental Change and Ecological Construction Er College of Ceography, Nanjing Normal University, Nanjing, 210097, China \\ ' Key Laboratory of Western China's Environmental Systems (Ministry of Education) E College of Resources and Environment, Lanzhou University, Lanzhou, 730000, China \\ a Dept Ciencias de la Tierra, Estratigrafia, Universidad de Zaragoza, 50009 Zaragoza, Spain
}

Editor: G.J. Weltje

\section{Keywords:}

Tianshui basin

Lake deposits

Mudflat

Calcretes

Eolian deposits

Correlations

Neogene

\begin{abstract}
A B S T R A C T
Guo's et al. comments on our paper (Z.T. Guo, J.Y, Ge, G.Q. Xiao, Q.Z. Hao, H.B. Wu, T. Zhan, L. Liu, L. Qin, F.M. Zeng, B.Y. Yuan, Comment on "Mudflat/distal fan and shallow lake sedimentation (upper Vallesian-Turolian) in the Tianshui Basin, Central China: Evidence against the late Miocene eolian loess" by A.M. Alonso-Zarza, Z. Zhao, C.H. Song, J.J. Li, J. Zhang, A. Martín-Pérez, R. Martín-García, X.X. Wang, Y. Zhang and M.H. Zhang [Sedimentary Geology 222 (2009) 42-51], Sedimentary Geology, 2010-this issue) mostly stress their previous data and their model of configuration and evolution of the study area; it is not a real discussion of the sedimentological features we describe. In this reply we will discuss some of the key features of the basin configuration, correlations and sedimentology of the Tinshui basin. Our work has followed the common procedures used in stratigraphy and sedimentology and so we can confirm our interpretation on basin configuration and correlations. In all cases we have taken into account previous papers, including those of Guo's group. In addition the sedimentological model we proposed is new due to the lack of previous sedimentological studies, including facies analysis and petrography, in the studied area. Our model of a continental alluvial-lacustrine basin fits well with other well-known examples over the world and explains clearly the lateral facies transitions across the basin. It is not the aim of this reply to discuss all the previous papers by Guo's group, but to reply to their main comments on our paper.
\end{abstract}

\section{Introduction}

First of all, we thank the authors Guo et al. (2010-this issue) for their detailed discussion of our paper and would like to take this opportunity to discuss some of the key aspects of the sediments and paleogeography of this subbasin of the Longzhong Basin. We would like to stress that our paper (Alonso-Zarza et al, 2009) presents a sedimentological study of the Tianshui Basin, including the Tianshui and Qinan regions. As a preliminary assessment, we established the main stratigraphic units and their correlations. For some reason, however, this part of our study was a main cause of disappointment for Guo's group despite having been carefully conducted according to the procedures commonly used in sedimentary basin analyses. In as much as possible, we followed the steps proposed by Miall (2000), including: a) determining the chronostratigraphic framework according to the lithostratigraphy, biostratigraphy and magnetostratigraphy and, b) interpreting each sequence in terms of depositional systems using petrographic, sedimentological data and principles of facies analyses. For the time being, ours is the only available sedimentological study of these Tertiary basins in central China, and the only study in which facies and microfacies are described. Of course, our paper only deals with Unit II of a part, or subbasin, of Longzhong Basin, the Tianshui Basin, and thus more detailed stratigraphical and sedimentological studies are needed to obtain a better and more detailed paleogeographical model. However, this does not mean that our paper ignores those by Guo's group (there are many references to their work), or that our conclusions are, as Guo et al. indicate, handicapped by poor documentation of geological background, sedimentology (in effect ours is the first real sedimentological paper) and chronology. More than $70 \%$ of our paper is devoted to describing and interpreting the sedimentological features we recognize 
in Unit II, yet Guo's discussion simply stresses their previous data and their model of configuration and evolution of the study area; it is not a real discussion of the sedimentological features we describe. Our reply focuses on the aspects considered in our paper, such as basin configuration, correlations and sedimentology. It is not our intention to discuss all the papers and data previously published by Guo et al., since this would require commenting on 15 papers or so.

\section{Basin configuration}

The Qinling orogen preserves a record of late mid-Proterozoic to Cenozoic tectonism in central China (Ratschbacher et al., 2003). Despite knowledge of the Cenozoic uplift of the Qinling Mountains since the work of Young et al. (1943), in their discussion Guo et al. indicate intensive uplift near the Tibetan Plateau during the late Miocene (Molnar, 2005) but they do not accept the idea of Miocene reactivation. Field studies and more recent papers (Wang et al., 2006) indicate that since the middle-late Paleogene, the NFFWQ (North Front Fault of Western Qinling) has played a very important role in tectonic deformation and basin evolution in this region. In the Longxi and Wushan regions, north of Qinling, thrust-faulting movements predominated over most of the Cenozoic, whereas strike-slip movement in the middle of the fault belt probably did not occur until the Miocene. The LongxiBasin developed on the north side of the NFFWQ as a foreland basin from the middle-late Paleogene to the late Miocene, where thick layers of Cenozoic sediments were deposited. The entire NFFWQ belt has undergone strong compression since the late Miocene. Thrust and deformation are also clearly apparent in the Ganquan section at the southern margin of the Tianshui Basin (GBS, 1968). For both the Longxi and Tianshui basins, the foredepth is distributed along the Weihe River close to the NFFWQ, while the foreland bulge occurs in the northern region along the eastward extension of the Maxianshan Mountains including Huajialing (Wang et al., 2006).

The distribution of Neogene sediments across a large and wide sedimentary basin is consistent with the tectonic setting and also with the lack of ridges within the basin. In their discussion, Guo et al. indicate that our sections are located in different sedimentary units separated by higher rocky ridges. As can be appreciated in our map and also in the map of these authors (see Fig. 1 in Alonso-Zarza et al., 2009), the sections appear in the same large sedimentary basin and there are no highlands or ridges between the different sections, such that they all belong to the same sedimentary basin. As seen in both maps, the Lamashan section is the only one in the southern intermountain area (Xihe-Lixian Basin), which was probably connected to the Tianshui basin up until the late Neogene or perhaps Quaternary (Zhang, 2008). It is difficult to understand why Guo et al. refer to an erosion stage in the late Pliocene to define the configuration of Miocene basin.

\section{Correlations}

Guo et al. strongly argue against the way in which we tackled our stratigraphic correlations. However, they fail to propose a stratigraphic sketch to explain the lateral and/or vertical change from loess deposits to lacustrine ones, as shown in their map. Our stratigraphic sketch tries to depict not only a simple lithological correlation, but also a correlation that serves to explain how the basin evolved. In continental basins, tectonism and climate (Hanneman and Wideman, 2010) are the major controls on the sedimentary infill pattern, with sedimentation of the different units viewed as a response to the relationship between potential accommodation space and sediment plus water supply (Carroll and Bohacs, 1999). Correlations in continental deposits are much more difficult than in the marine realm, since there is a lesser abundance of fossil remains and also due to greater lateral and vertical changes. As indicated in our paper, the chronological framework we propose was based on magnetostratigraphic data (Guo et al., 2002; Li et al., 2006) along with mammal fossil evidence (Zhai, 1959; 1961; Zhang, 2008). All the units and sections examined are Neogene in age. At the Yanwan section, two horizons contain Hipparion fauna attributed to Vallesian and Turolian stages; this would definitely be consistent with the interpretation based on paleomagnetic data. In addition, the paleomagnetic results for the Lamashan and Yaodian section indicate approximately the same ages for Unit II (Zhang, 2008).

The Ganquan section is one of the more proximal sections close to the thrust fault. Apart from the fossil evidence proposed by Geological Bureau of Shaanxi (GBS) (1968), the visible continuity of the Neogene deposits across the basin and their lateral or vertical development confirm the Ganquan section is Neogene in age. Here, below the Neogene, the Ganquan section also harbors continental Paleogene sediments. Paleogene and Neogene deposits are bounded by an angular unconformity between different beds of coarse conglomerates (Fig. 1A, B). Recent studies based on detrital apatite fission-track thermochronology (Wang in prep.) have also demonstrated the Neogene age of part of the Ganquan section.

With respect to the Yaodian section and probably to some of the others, we should remind the reader that we focused our study on Unit II, such that some parts of Unit I, III or IV are not included in our Figs. 2 and 3 (Alonso-Zarza et al., 2009), indicating our logs do not record the complete sections, although most of them. As may be seen in Fig. 3 of Alonso-Zarza et al. (2009), our Yaodian section is younger than QA-I. In addition, we would like to stress that in our Fig. 2, we tried to show the approximate situation of the sections, but that this is not that easy. This is because in the vertical scale we show time and the sections show thickness and in some cases a thick section could be deposited in a relative short period of time or vice-versa. The locations of the sections in Fig. 2 should therefore be only considered as relative.

\section{Sedimentology}

Our paper mainly addresses the sedimentology of the deposits of this region of central China. However, in their discussion Guo et al. provide very few arguments against our field and petrograpic observations. Their discussion stresses over and over again their previous data, offering very few proven facts questioning our data. At this point, we will try to reply to their main concerns regarding our sedimentological proposal.

1) Correlative stratigraphy does not inform of the depositional setting and neither does grain size analysis. The fact that the beds can be correlated over long distances does not indicate they are eolian. In addition Guo et al. argue that waterlain sequences are unable to correlate long distances in detail, but why? What type of waterlain deposit do they mean? What we propose is a transition from alluvial fans to lakes. Several large continental basins across the world both in ancient and modern times are like this and show a great variety of deposits that, of course, can be correlated over long distances through correlations that also take into account lateral facies changes. A classic example may be found in the Green River Formation (Eugster and Hardie, 1975).

2) The study and arguments by Guo related to grain size analysis pose too many questions. How carbonate content was measured?. It is well established that the beds considered as Neogene loess by Guo's et al. show higher carbonate contents (15.76\%-46.34\%) than Quaternary loess deposits (5-25\%) (Liu, 1985). Our petrographical studies indicate that the sediments bear substantial amounts of carbonate forming a matrix (micrite), grains (Fig. 2A) or cements (Fig. 2B). Some beds show over $50 \%$ of micritic carbonate $(<4 \mu \mathrm{m}$ across) while others have large carbonate intraclasts more than $2 \mathrm{~cm}$ across that have ignored. Why did they ignore these beds?, and why did they ignore the carbonate content? They offer 

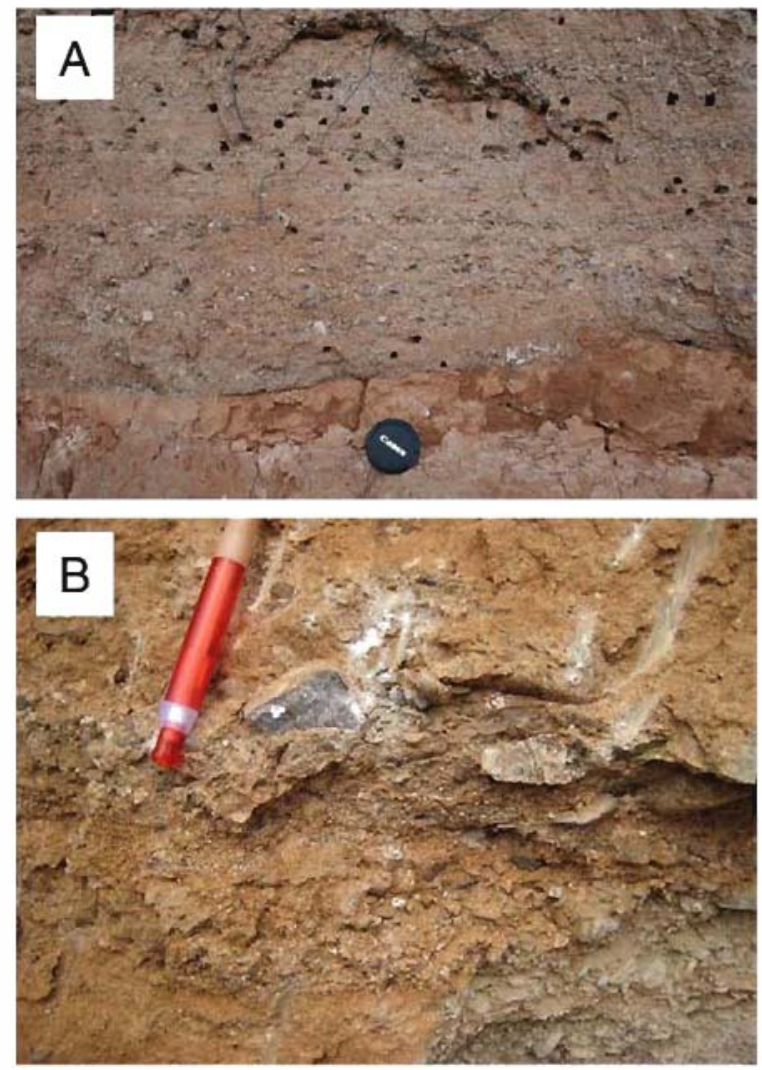

Fig. 1. A Gravel bed at Ganquan section, approximately $400 \mathrm{~m}$ above the Neogene/ Paleogene boundary. The base is erosive on fine red clastic. The diameter on the lens cap is $6 \mathrm{~cm}$. B. Detailed view of a gravel bed deposits in the Neogene of Ganquan section. It deposited by alluvial fan bodies coming from the Quinling Mountains. (For interpretation of the references to color in this figure legend, the reader is referred to the web version of this article.)

considerable information, are common in many of the sections, and are very good diagnostic features. The mechanism and environment of carbonate formation and reworking have to be explained. It is difficult to explain all these processes considering that the sediment is loess, whereas all these features are very common and easily explained within the sedimentary environment we propose. In addition, if the samples of coarse grain size are not considered, they are narrowing the scope of the grain sizes possible to find and the results maybe not correct, perhaps the fines are not so fine or so silty, because they includecarbonate and sand-gravel sized clasts.

3) Our statement that grain size rapidly decreases from south to north refers, as indicated in the paper, to the southern margin of the Tianshui Basin. From this margin to the north, clastic deposits rapidly pass to finer grained muds with interbedded carbonate layers. There is also a decrease in grain size from north to south in relation to the Huajialing Mountains. Thus, the grain size distribution is determined by the location of the main sediment source areas, the Qinling Mountains to the south and the Huanjialing Mountains to the north, with carbonate deposition occurring in inner areas. This trend is consistent with that commonly observed in continental basins such as the Eocene Guarga Formation of the Pyrenees (Nickel, 1982) and the Miocene of the Duero (Huerta and Armenteros, 2005; Armenteros and Huerta, 2006) or Madrid Basin (Alonso-Zarza et al., 1992).

4) Land snails thrived during the dry (dominant) periods within the mudflats, which are also subaerial environments where the calcretes formed. Hence, these snails cannot be described as
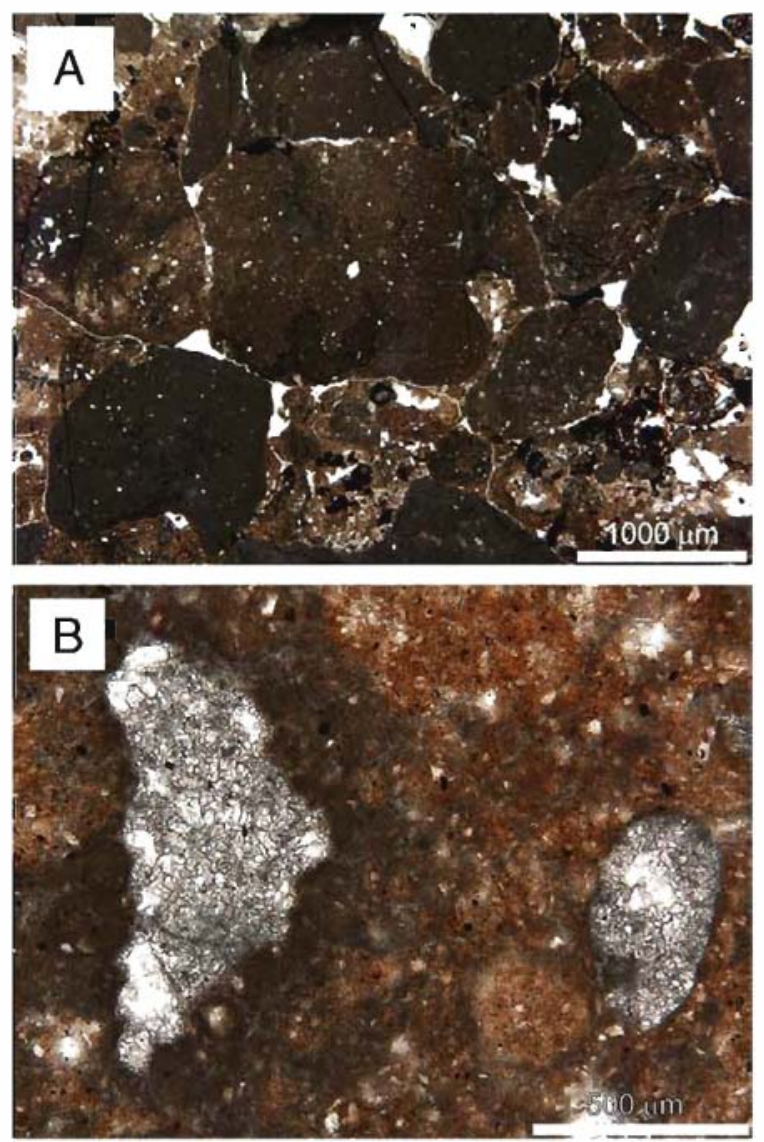

Fig. 2. A. Carbonate intraclasts occur in many of the studied beds. This picture is a microphotograph so the larger intraclasts is about $1 \mathrm{~mm}$ across, but hand samples show much larger ones. Unit II. QA-I section. B. Fine red clastic sediments showing both coarse phreatic cements and micrite. Unit II. QA-I section. (For interpretation of the references to color in this figure legend, the reader is referred to the web version of this article.)

contrasted evidence of eolian deposits, rather they only indicate dry areas such as those reflected in our model. In addition, it should be noted that our model fits the paleogeography revealed by widespread mammal fossils in this region, including two previously reported locations at Lianhua and Guojia, where Platybelodon, Aceratherium, Gomphotherium connexus, Serridentinus sp. have been detected (Zhai, 1959; 1961). Platybeldon is believed to have lived on prosperous aquatic vegetation (Borissiak, 1929; Deng, 2004).

5) The presence of soils is not inconsistent with a mud/flat lake environment. In our paper we describe different calcrete types and pedogenic features indicating subaerial environments. In addition, some features such as the coarse calcite cements (Fig. 2B), which are phreatic cements (James and Choquette, 1984), and the presence of palustrine features clearly indicate high groundwater tables and shallow water bodies (Freytet and Verrecchia, 2002; Alonso-Zarza, 2003; Armenteros and Huerta, 2006; Alonso-Zarza and Wright, 2010), which are difficult to explain within loess deposits.

6) Throughout the text and also in their figure captions, Guo et al. refer to waterlain deposits. Within this term they include all the types of facies we describe, from distal fan/mudflat facies associations to lacustrine ones. These facies associations interfinger laterally and vertically and many of them are subaerially exposed. The term waterlain is so wide that it does not say much about the sedimentary environments we try to describe. For example in their Fig. 1, they try to show our sections, considering 
them all as "waterlain"; this is really an oversimplification of what may be seen in the pictures, even at this resolution. In addition, the pictures they provide do not exactly correspond to the sites where the sections were taken and it is not possible to see any clear sedimentological feature within them, rather only a vague idea of their appearance can be obtained.

7) We do not rule out a possible contribution of eolian particles to this area of the basin and, as indicated in our paper, some extrabasinal clastic components could have been supplied by wind. The contribution of eolian dust to shallow lake deposits associated with floodplains and even deltaic sequences has also been recognized within the Triassic Mercia Mudstone Group of Great Britain (Talbot et al., 1994). The Mercia Mudstone group also contains ripples, small scour depressions and brecciated horizons capped by desiccation surfaces, micritic limestones and also ooidal grainstones and packstones (Talbot et al., 1994). All this indicates that the red mudstones were deposited in playa lake systems on very wide alluvial plains, from ponded flood waters brought to the basins after exceptional rains. In this setting, some of the silt-size grains are probably also of eolian origin. Although with some differences, especially the lack or scarcity of evaporites in our study case, the depositional environments envisaged for the Mercia Mudstones are yet another example of an alluviallacustrine basin dominated by fine-grained sediments in which transitions between fine-grained alluvial red sediments to lacustrine ones are as common as those shown in Fig. 2 of our paper (Alonso-Zarza et al, 2009).

\section{Concluding remarks}

In this reply we have tried to put forward our arguments for the tectonic setting, stratigraphy and sedimentology of the Tianshui Basin. In doing so, we stress that our data are based on detailed studies but also take into account previous documentation of the geological background and chronology. As in our paper, we also consider the possibility that some of the silt-grain sizes could have been sourced by wind, as in the cases of other well know alluvial-lacustrine basins, but does this does not imply that the overall deposit is loess. Finally, we would have preferred if the discussion by Guo et al. had focused more precisely on the sedimentological descriptions and model we propose. As we see it, their comment on our paper insists on detailing their arguments in favor of loess more than discussing the sedimentological features we present.

\section{Acknowledgements}

The authors thank Prof. Shi Y. F. for constructive suggestions, and Drs. Hui Z., Meng Q., Shu Q., Cui Q. and Liu Y., for their valuable help both in the field and laboratory. This study was supported by the National Basic Research Program of China projects Tibetan Plateau (2005CB422001) and NSFC (40721061). The Spanish group was supported by projects CGL2008-05584-C02-02, from MCINN and 910404 by UCM-CAM-BSCH.

\section{References}

Alonso-Zarza, A.M., 2003. Palaeoenvironmental significance of palustrine carbonates and calcretes in the geological record. Earth Sci. Rev. 60, 261-298.

Alonso-Zarza, A.M., Wright, V.P., 2010. Palustrine carbonates. In: Alonso-Zarza, A.M., Tanner, LH. (Eds.), Carbonates in Continental Settings: Facies, Environments and Processes. Developments in Sedimentology, 61. Elsevier, Amsterdam, pp. 103-132.
Alonso-Zarza, A.M., Wright, V.P., Calvo, J.P., Garcia del Cura, M.A, 1992. Soil-landscape and climatic relationships in the Middle Miocene of the Madrid Basin. Sedimentology 39, 17-35.

Alonso-Zarza, A.M., Zhao, Z., Song, C.H., Ii, J.J., Zhang, J., Martín-Pérez, A., Martín-García, R., Wang, X.X., Zhang, Y., Zhang, M.H., 2009. Mudflat/distal fan and shallow lake sedimentation (upper Vallesian-Turolian) in the Tianshui Basin, Central China: evidence against the late Miocene eolian loess. Sed. Geol. 219, 42-51.

Armenteros, I., Huerta, P., 2006. The role of clastic sediment influx in the formation of calcrete and palustrine facies: a response to paleogeographic and climatic conditions in the southeastern Tertiary Duero Basin (northern Spain). In: AlonsoZarza, A.M., Tanner, L.H. (Eds.), Paleoenvironmental Record and Applications of Calcretes and Palustrine Carbonates. Geological Society of America. Special Paper, 416, pp. 119-132.

Borissiak, A., 1929. On a new direction in the adaptive radiation of mastodonts. Palaeobiologica 2, 19-33.

Carroll, R.A., Bohacs, K.M., 1999. Stratigraphic classification of ancient lakes: balancing tectonic and climatic controls. Geology 27, 99-102.

Deng, T., 2004. Evolution of the Late Cenozoic mammalian faunas in the Linxia Basin and its background relevant to the uplift of the Qinghai-Xizang Plateau. Quaternary Sciences 24 (4), 413-420 in Chinese with English abstract.

Eugster, H.P., Hardie, L.A, 1975. Sedimentation in an ancient playa lake complex: the Wilkins Peak member of the Green River Formation of Wyoming. Bull. Geol. Soc. Am. 86, 319-334.

Freytet, P., Verrecchia, E.P., 2002. Lacustrine and palustrine carbonate petrography: an overview. J. Paleolimnol. 27, 221-237.

Geological Bureau of Shaanxi (GBS), 1968. Report of Regional Geological Surveys of People's Republic of China, Tianshui $(1: 200,000)$. Survery Team Publishing House, Wugong, pp. 1-74.

Guo, Z.T., Ruddiman, W.F., Hao, Q.Z., Wu, H.B., Qiao, Y.S., Zhu, R.X, Peng, S.Z., Wei, J.J., Yuan, B.Y., Liu, T.S., 2002. Onset of Asian desertification by $22 \mathrm{Myr}$ ago inferred from loess deposits in China. Nature $416,159-163$.

Guo, Z.T., Ge, J.Y., Xiao, G.Q., Hao, Q.Z., Wu, H.B., Zhan, T., Liu, L, Qin, L., Zeng, F.M., Yuan, B.Y., 2010. Comment on "Mudflat/distal fan and shallow lake sedimentation (upper Vallesian-Turolian) in the Tianshui Basin, Central China: Evidence against the late Miocene eolian loess" by A.M. Alonso-Zarza, Z. Zhao, C.H. Song, J.J. Ii, J. Zhang, A. Martín-Pérez, R. Martín-García, X.X. Wang, Y. Zhang and M.H. Zhang [Sedimentary Geology 222 (2009) 42-51]. Sed. Geol. 230, 86-89 (this issue).

Hanneman, D.L., Wideman, C.J., 2010. Continental sequence stratigraphy and continental carbonates. In: Alonso-Zarza, A.M., Tanner, L.H. (Eds.), Carbonates in Continental Settings: Geochemistry, Diagenesis and Applications. : Developments in Sedimentology, 62. Elsevier, Amsterdam, pp. 215-273.

Huerta, P., Armenteros, I., 2005. Calcrete and palustrine assemblages on a distal alluvialfloodplain: a response to local subsidence (Miocene of the Duero Basin, Spain). Sed. Geol. 177, 235-270.

James, N.P., Choquette, P.W., 1984. Diagenesis 9. Limestones - the meteoric diagenetic environment:. Geosci. Can. 11, 161-194.

Li, J.J., Zhang, J., Song, C.H., Zhao, Z.J., Zhang, Y., Wang, XX., Zhang, J.M., Cui, Q.Y., 2006. Miocene Bahean stratigraphy in the Longzhong Basin, northern central China and its implications in environmental change. Science in China (D) 49, 1270-1279.

Liu, T.S., 1985. Loess and the Enviroment. China Ocean Press, Beijing. 400 pp.

Miall, A.D., 2000. Principles of Sedimentary Basin Analysis. Springer, Berlin. 616 pp.

Molnar, P., 2005. Mio-Pliocene growth of the Tibetan Plateau and evolution of Asian climate. Palaeontologia Electronica 8, 1-23.

Nickel, E., 1982. Alluvial-fan-carbonate facies with evaporites, Eocene Guarga Formation, Southern Pyrenees, Spain. Sedimentology 29, 761-796.

Ratschbacher, L., Hacker, B.R., Calvert, A., Webb, L.E., Grimmer, J.C., McWilliams, M.O., Ireland, T., Dong, S., Hu, J., 2003. Tectonics of the Qinling (Central China): tectonostratigraphy, geochronology, and deformation history. Tectonophysics 366 , $1-53$.

Talbot, M.R., Holm, K., Williams, M.A.J., 1994. Sedimentation in low-gradient desert margin systems: a comparison of the Late Triassic of northwest Somerset (England) and the late Quaternary of east-central Australia. In: Rosen, M.R. (Ed.), Paleoclimate and Basin Evolution of Playa Systems. Spec. Pap. Geol. Soc. Am., 289. Boulder, CO, pp. 97-117.

Wang, Z.C., Zhang, P.Z., Zhang, G.L., Li, C.Y., Zheng, D.W., Yuan, D.Y., 2006. Tertiary tectonic activities of the north frontal fault zone of the west Qinling mountains: implications for the growth of the northeastern margin of the Qinghai-Tibetan plateau. Earth Sci. Front. 13 (4), 119-135 in Chinese with English abstract.

Young, C.C., Bien, M.N., Mi, T.H., 1943. Some geologic problems of the Tsinling. Bulletin of the Geological Society of China 23, 15-34.

Zhai, R.J., 1959. On a collection of Miocene mammals from eastern Kansu. Pleovertebrata et Paleoanthropologia 1, 139-140 in Chinese.

Zhai, R.J., 1961. On a collection of Neogene mammals from Ching-an, eastern Kansu. Vertebrata Palasiatica 5. 262-268 in Chinese.

Zhang, J., 2008. Formation cause of the Neogene sediments in Tianshui-Qin'an area in Longzhong Basin and the Paleoenvironmental change. Ph. D thesis. Lanzhou, Lanzhou University, pp. 1-141. http://epub.cnkinet/grid2008/detail.aspx?filename $=2008162377 . n$ \& dbname $=$ CDFD2008. 